Ispánovics Csapó Julianna

Filozofski fakultet Univerziteta u Novom Sadu
UDK 930.85(=511.141)"14"

Originalan naučni rad

\title{
KULTÚRAALAPÍTÁS A MAGYAR KIRÁLYSÁG DÉLI VIDÉKEIN ${ }^{1}$
}

\author{
„Új keresztény vagyok, mint \\ újonnan megkereszteltnek újak a \\ harcok, melyeket vívni akarok." \\ (Csanád szavai Szent Gellért \\ püspök nagy legendájából)
}

A vajdasági magyar kultúra történetére koncentrálva jelen dolgozat Margócsy István szintézis-értrelmezésének szellemében kísérli meg a vajdasági magyar kultúrtörténet alapvetésének, a magyar királyság déli vidéke, (a Dél-Alföld) kultúraalapítási csomópontjainak (Csanád, Aracs, Bodrog, Bács, Szerém) a szintetizálását. A Magyar Királyság déli országrészein kialakuló multietnikus közösségek alkotta kultúrkörök kelet és nyugat határán egy sokszínű, traumatizált kulturális entitás aktualitását (ha lehet szó ilyesmiről), továbbélési lehetőségeit is vizsgálja.

Kulcsszavak: kultúraalapítás, szintézis, Csanád, Aracs, Bodrog, Bács, Szerém, Magyar Királyság, Dél-Alföld, Vajdaság

\section{FOLYTONOSSÁG VAGY SZAKADOZOTTSÁG?}

A történelmi irodalmi hagyomány egységes képének az ideáját, ,az ,irodalomtörténeti egység varázsos utópiá”-ját (Margócsy, 2012, para. 2) bontja meg Margócsy István, amikor felhívja a figyelmet arra a könnyen belátható és elfogadható gondolatra, miszerint az irodalomtörténeti szintézisek, natrratívák, amelyek rendezőelve általában valamilyen irodalmon kívüli princípium, teremtik meg a valójában nem fellelhető, de létezőnek tekintett irodalomtörténeti folytonosság, „fejlődési vagy kibomlási séma” (Margócsy, 2012, para. 3) gondolatát. A homogén nemzeti kultúr- és irodalomtörténet modelljét az egyes diakron narratívák szerzői koruk tudományos gondolkodásából eredően egy természettudományi rendezőelv, az analógia módszere segítségével formálták meg:

...egy előre megalkotott (hisz másoknál már bevált) fejlődési rend uralkodik, melynek mind egysége, mind elemenkénti felépítettsége kétségbevonhatatlan -

csapo@eunet.rs 
amint a »nagy« történelemnek megvan írva a maga menete, úgy az irodalomban is ugyanazok a törvényszerüségek és jelenségek kell, hogy előforduljanak - ha pedig valami miatt mégsincsenek, akkor pótolni kell őket. (Margócsy, 2012, para. 3).

Az irodalmi entitások, jelenségek, folyamatok egységességének és folyamatosságának a vágya ellenében Margócsy az irodalmi halmaz megszakítottságát, darabosságát nevezi meg az irodalomtörténet legfőbb jellemzőjeként. Különösen igaz ez, emeli ki, ha a szövegek befogadástörténetét is bekapcsoljuk a történeti narratívák hálóiba. Ez az elgondolás a térben és időben megjelenő magyar irodalom és kultúra egészére vonatkoztatható. Megoldja a határokon túli irodalom és kultúra kezelésének a kérdését. „A történetiség többes száma” (irodalomtörténetek, kultúrtörténetek) többféle „történeti sor” fikcióját teszi lehetővé (Margócsy, 2012. para. 5). A vajdasági magyar kultúra, irodalom történetére koncentrálva jelen dolgozat a fentiek szellemében kísérli meg az alapvetés szintetizálását valamint a magyar királyság déli vidékein kialakuló korai kultúrkör elemei, jelenségei, jellemzői aktualitásának (ha van ilyen), továbbélési, termékenyítő lehetőségeinek a vizsgálatát.

\section{CSANÁD}

István király hadvezére, Ajtony egykori vitéze, a Szent György vértanúhoz fohászkodó Csanád 1027-1028 körül legyőzi a déli vidékek nagyhatalmú urát, Ajtonyt ${ }^{2}$. Marosvárott és környékén ekkoriban már görög szerzetesek tartanak fenn kolostorokat, irányítják és szervezik meg „,a letelepedett életmódot élő szlá-

2 „Akkoriban volt Marosvárt egy Ajtony nevü nagyon hatalmas fejedelem, aki Bodony városában a görögök szertartása szerint keresztelkedett meg.(...) Marosvárott Keresztelő Szent János tiszteletére monostort épített, $\mathrm{s}$ abba apátot helyezett görög szerzetesekkel, az ő rendszabályuk és szertartásuk szerint. Mivel ennek az embernek szolgált a Körös folyótól az erdélyi részekig és Bodonyig és Szörényig terjedő föld, s mindezt a hatalma alá vonta, ezért fegyvereseinek sokaságával túltett másokon, a királyt pedig semmibe vette.(...) Csanád pedig arra az éjszakára tábort ütött egy hegynél, amelyet aztán Oroszlánosnak nevezett el. Ajtony meg a Nagyősznek mondott mezőn vert tábort. Mindkét fél őrszemei aztán virrasztva fel és alá járkáltak. Csanád pedig álmatlanul töltve az éjszakát, Szent György vértanúhoz könyörgött, hogy esdje ki számára az ég Urának segítségét. Fogadalmat is tett, hogy ha ellenségén győzelmet arat, az imádság helyén - ahol a földön térdelt - monostort emel a tiszteletére. És mikor a felette nagy megeröltetéstől és fáradságtól elnyomta az álom, álmában egy oroszlán alakja jelent meg neki; megállt a lábánál és szólt hozzá: „Ember, mit alszol! Kelj fel tüstént, fújd meg kürtödet, menj, kezdj ütközetet és legyőzöd ellenségedet." És mikor felébredt, úgy tünt neki, mintha két ember erejét kapta volna meg. Azután összegyüjtötte seregét, elbeszélte nekik az álmot, amelyet látott és így szólt: „Imádságom után, amelyet leborulva sokáig végeztem az Úr és Szent György vértanú előtt az éjjel, álom nyomott el, s mintha egy oroszlánt láttam volna, amint ott állt a lábamnál, körmeivel rázott és azt mondta: „Kelj föl, ember, mit alszol! Seregedet szedd össze, menj az ellenségre, most éppen alszik, győzd le!’”..) Késedelem nélkül harcba szálltak hát, és Szent György vértanú érdemeiért, aki őket oroszlán alakjában látogatásra méltatta, várták az ég segítségét. És nemsokára azon az éjszakán egymásra rontottak; Ajtony serege, mely a síkságon táborozott, hátat fordítva futásnak eredt. Ajtonyt pedig Csanád serege a csata helyszínén megölte. Fejét levágták és elküldték a királynak. Ezen a napon rengeteg zsákmányt ejtettek, és elteltek nagy örömmel, hogy a király ellensége elesett. A harcban elesett keresztények holttestét pedig felszedték, Marosvárra vitték, és a Keresztelő Szent János egyház temetőjébe, a görögök monostorába temették el, mert más monostor azon a vidéken abban az időben nem volt. E város egyharmada pedig a hely szerzeteseinek szolgált. Csanád nem üzte el őket, hanem megengedte, hogy abban az állapotban maradjanak, amelyben találta őket.(...) Ezek után Csanád elment arra a helyre, ahol az oroszlánt látta álmában, ott Szent György 
vok, görögök és a görögkeleti vallást követő magyarok vallási életét" (Pálinkás, 1984, 9). Dávid szerint ,a terület bizánci érintettsége nem Ajtonnyal kezdődött, hanem Zombor gyulának 10. század derekán történt megkeresztelkedésével, aki Bizáncból missziós püspököt hozott magával" (Dávid, 1996, para. 14). Más forrás szerint „Az első magyar királyok lelkesen támogatták a görögkeleti egyházat, akár görög, akár ószláv nyelven hirdette is az igét, de a római egyház nagy nyomására az 1054-ben bekövetkezett szakadás után az utóbbi került fölénybe a magyar államban” (Pálinkás, 1984, 10). Szegfü László a bogumilizmus magyarországi megjelenését Aba Sámuellel, Vatával, Gyulával és Ajtony vezérrel hozza kapcsolatba (Szekfü, 1968). A pogánynak tartott vezérek szerinte megtévedt görögkeleti keresztények, eretnekek voltak. A magyar földön megjelenő, NyugatEurópa és a Baltikum irányába terjedő eretnek tanokat a katolikus egyház veszélyesebbnek tartotta a pogányságnál, ezért a magyar királyság déli vidékein megjelenő Gellért egy nagyhorderejü missziós feladattal találja magát szemben. Szegfü állítása nem igazolható, de nem is cáfolható egyértelmüen, hiszen „Mivel a bogumil tanok szláv területen alakultak ki, és a Balkánon is szláv területen terjedtek, logikus azt feltételeznünk, hogy Ajtony territóriumán belül is a szláv lakosság körében verhettek elöször gyökeret. Tölük azonban hamar átvehették a magyarok is, különösen akkoriban, amikor Ajtony uralmának bukása és a csanádi püspökség megszervezése (1030) után a területen jelentős keresztény térítés kezdődött" (Ternovácz, 2013, 518).

Ajtony vereségét követően István király a Tisza-Maros-Duna-közi területen létrehozza Csanád vármegyét, melynek székhelye Marosvár, új nevén Csanád (a győztes vezér neve után). Magyarország ekkoriban keresztes határvidék, olyan terület, ahol a hittérítő keresztények érdemeket szerezhetnek, előnyöket nyerhetnek, akár Palesztinában (Györkös, 1998). Ezen a vidéken jön létre 1030 körül a csanádi egyházmegye. A király a Velencéből jött bencés szerzetest, Gellértet teszi meg a terület püspökévé, aki rendtársaival Csanádon, az Oroszlámosra áthelyezett ortodox szerzetesek monostorában telepedik le, és kezdi meg a térítő, tanító munkát. Gellért püspökségét Szűz Máriának ${ }^{3}$ szenteli. Az egyházmegye központi épületei, szervei az egykori római castrum helyén jönnek létre. Itt épül fel királyi támogatással a Szent György székesegyház ${ }^{4}$, a Szüz Mária monostor (a mai orto-

vértanú tiszteletére monostort épített, és oda telepítette Keresztelő Szent János monostorából az említett görög szerzeteseket apátjukkal együtt.” (Szent Gellért, 1983)

3 Gellért javaslatára a térítők a magyar ősvallás anyaistennőjét, a Boldogasszonyt Szűz Máriával helyettesítették be (Jankovics, 2007). „Mindkettőnél nem egyszerűen asszonyról van szó, hanem egy életet adó személyről. A szeplőtelen fogantatáshoz igen hasonló mitológiánk Emeséje is, éppen ezért mi magyarok Máriát Szüz Máriának nevezzük, holott őt az európai kereszténység Szent Máriának (Heilige Marianak, Santa Marianak stb.) nevezi. Öseink istenanyja nem az európaiak által ábrázolt Holdon, hanem a Napon, illetve a Napot szimbolizáló kereszten áll. Szent Gellért térítő törekvései során találkozott egy jóságos, fenséges mennyei asszony kultuszával, akiben mintegy Szűz Mária előképét láthatta, akinek tisztelete nagyobb akadály nélkül válhatott Mária-kultusszá, és akinek költői neve sem látszott méltatlannak arra, hogy Isten anyját ékesítse. Ekkor választotta ki Szent Gellért a „Napba öltözött asszony” bibliai idézetét az udvar előtt tartott prédikációjának témájául" (Kiszely, 2001).

4 A középkori Szent György kultusszal összhangban a szentnek, a lovagok patrónusának Gellért életében is kiemelt helye van. Szülei Györgynek keresztelik. Ötévesen súlyosan megbetegszik, ezért apja és anyja 
dox templom helyén) és a középkori Magyarország első káptalani (székesegyházi) iskoláinak egyike a csanádi iskola, melynek első oktatói Walter magiszter és később a székesfehérvári Henrik szerzetes (Pálinkás, 1984). A monostor a maga nemében egyedülálló a korabeli Magyarországon. A korai királyi alapítású bencés apátságok általában a püspöki székhelyek közelében, de nem magában a városban jönnek létre. Gellért valószínúleg velencei mintára városi monostort alapít. Ez a szervezeti forma egy aktív missziós jelenlétre, egyházkormányzati tevékenységre, szándékra utal. A nyugat-európai püspöki magánmonostor típusa nem honosodik meg magyar földön (. A középkori Magyarországon 1046. szeptember 26-án a lázadó pogányok megölik Gellért püspököt, holttestét utóda 1053-ban Pestről Csanádra viteti át és temetteti el újra ${ }^{5}$.

Csanád vármegye négy ötöde 1241-42-ben, a tatárdúlás során pusztul el, véglegesen a tizenötéves háború (1591-1606) népteleníti el, amikor a várost és a Szent György székesegyházat 1552-ben felperzselik a törökök. A püspöki székhely szakrális értékei a szegedi ferences múzeumba kerülnek (Dávid, 1996).

a velencei bencések Szent György monostorába viszik, lovagszentnek ajánlják fel. A Gellért nevet tizenöt évesen, apja emlékére veszi föl. Mintaszerü szerzetes lesz belőle, Bolognában tanul, majd a velencei Szent György kolostor apátja (Török, 1991).

5 „Mikor tehát Szent Gellért teste hét évig feküdt abban a földben, ahol eltemették, Mór csanádi püspök és Fülöp, a Boldogságos Szűz csanádi monostorának apátja, akit még maga Szent Gellért tett meg e monostor apátjának, a csanádi püspökségből való sok nemessel együtt András király elé járultak, és kérték, engedje meg, hadd vigyék el szabadon Marosvárra Szent Gellért vértanú testét, amely a Boldogságos Szűz kápolnájában, Pesten volt eltemetve. Ezt a kérésüket teljesítették, és mikor a szent vértanú sírjához mentek, koporsójából csodálatos illat tört fel, és testét oly ragyogónak találták, mint a hó, mintha abban a szempillantásban szenvedte volna el a vértanúságot.

Mikor pedig a szent testet vitték, a nyomorékoknak, vakoknak, sántáknak nagy tömege sereglett oda, s ezek testének vagy ruhájának érintésére mind meggyógyultak. És mivel a tömérdek nép miatt nappal nem tudtak elindulni, éjjel indultak útnak. Mikor egy darabot már mentek, egy béna asszonynak a keze, ahogy a szent testet megérintette, tüstént meggyógyult. Ezenfelül az igavonókat, amelyek a szekeret húzták, nem látták enni, se inni, s mindig könnyedén húzták, mintha semmi terhet nem éreznének. A falvakból és az egész csanádi tartományból tódultak az emberek a férfiú teste elé, hogy az, aki őket a hitre térítette, a Magasságbelinél is méltóztassék értük közbejárni. Mikor aztán a Maros folyóhoz értek és szokott módon a szekér a testtel együtt már a hajón volt, a hajót az egész sokaság sem tudta elindítani, de ahogy az evezőket eldobták kezükből, a hajó olyan sebesen szelte a vizet, ahogyan semmiféle emberi mesterséggel nem mehetett volna át.

Ott pedig Fülöp apát a kanonokokkal és szerzetesekkel, ünnepi papi díszben a szent testet felemelve nagy körmenetben a Boldogságos Szűz monostorába vitték, amelyet életében még maga épített temetkezési helyéül; Keresztelő Szent János temploma mellé. Fülöp apát és a kanonokok között szóváltás támadt. A kanonokok azt hajtogatták, hogy a székesegyházban kellene temetni. Fülöp apát viszont apostoli határozat alapján, amelyet ez a férfi még életében megszerzett temetkezési helyével kapcsolatban, azt állította, hogy a Boldogságos Szüz monostorában kell eltemetni. Végre is a kanonokok a szent testet elöször Szent György templomába vitték, de ott semmiképpen nem tudták letenni, nem engedte ugyanis magát letenni, csak a mondott helyen, hol a sírhelyét kiválasztotta. Ezért azok, akik a koporsót vitték, követték a csodát, és mentek, amerre akaratuk ellenére vitte öket. Mikor a mondott sírhelyhez értek, oly súly nehezedett azokra, akik a szent testet vitték, hogy - amint később mindegyikük beszélte - ha útközben szakadt volna rájuk az a súly, ott hagyták volna a testet. Végül is, mivel a népsokaság miatt nem temethették el, sőt néhány hétig a templomban istentiszteletet sem lehetett tartani, ezért tanácsot tartottak, és a népnek nagy lakomát rendeztek; s míg együtt lakomáztak, az apát a püspökkel és szerzetesekkel, zárt ajtók mögött, a tiszteletreméltó testet illő tisztelettel és hódolattal eltemette. Ruháját pedig, amelyben megölték - ennek csuklyája, más néven kámzsája is volt -, teveszőr köpenyét, a követ, amellyel agyonsújtották, ciliciumát és korbácsát, amikkel a testét sanyargatni szokta, mind a sírja fölé tették." (Szent Gellért, 1983) 


\section{ARACS}

„Csanádtól délre, a Tisza bal partján - egykor ez is Ajtony szállásterületéhez tartozott - Aracson egy 13. századi templomrom állt. Az itt végzett föltárások kimutatták, hogy ezt a templomot egy 10. századvégi egyház előzte meg, tehát egy olyan, amely egyidős volt a Csanádival" (Dávid, 1996, para. 3). 1091-ben, az első kun betörést követően alapíthatta István király az aracsi bencés monostort, amit a török hódításig hiteles helyként tartanak számon. A ma látható román kori templom a 13. század első harmadában, valószínűleg egy korábbi templomot felváltva épült (az előzmény létére az 1896-ban előkerült ún. aracsi kő utal). A Szent Mihály tiszteletére alapított benedekrendi apátság temploma háromhajós, háromapszisos, boltozott, kolostori téglabazilika. A szerkezeti elemek nagy része kőburkolattal ellátva vagy kőből készült, akár a díszítőfaragványok. A szürkésfehér kőanyag a Sóvár (Szalánkemén, Slankamen) tájáról, a Fruška Gorából származik. A vörös mészkőből készült padlólapok, oszloptörzsek és lábazatok alapanyaga valószínüleg Erdélyből érkezett. Raffay Endre müvészettörténeti elemzései nyomán egy jelentős egyházművészeti örökség nyomai mutatkoznak meg. A pusztatemplom alaprajza, a pillérformák és a szentélyrész előtti szakasz a Csák nemzetség vértesszentkereszti templomának, boltozati rendszere pedig a franciaországi Bourges székesegyház megoldásaival rokonítható. A díszítőfaragványok egy része antikizáló kompozíciójú. Ezek az esztergomi királyi palota és az érseki székesegyház provence-emiliai eredetủ stílusrétegének a hatásáról tanúskodnak: mestereik a tudásukat ott szerezték. A faragványok egy másik csoportja gótikus jellegü, egy közülük a Pannonhalmi Bencés Főapátsági templom reimsi kapcsolatú faragványaival mutat összefüggést (Raffay, 2005). A pusztatemplom környékén terül el a Becsevárához tartozó Aracsa település, amely a XV. században vásáros hely, virágzó mezőváros (Kalapis, 1993).

Aracsot először nagy valószínüséggel a kunok dúlják föl IV. László uralkodása idején (1280). 1536-ban egy pestisjárvány tizedeli meg Aracsa lakóit, majd 1551-ben a Becse vára alá érkező Begler bég szeptember 18-án Aracs megerösített kolostorát is elfoglalja, sorsára hagyja. Aracs védői az első ágyúlövések után elmenekülnek a kolostor utolsó lakóival együtt. A menekülés valószínüleg a becsei várral összekötő alagúton keresztül történik. Tinódi Lantos Sebestyén Aracs török kézre jutását a Siralmas Krónikában említi meg (Szügyi, 2008).

\section{BODROG}

A Duna-Tisza közének déli részén elterülő Bodrog vármegye központja Bodrog vára. Gubitza Kálmán a Monostorszeg (Bački Monoštor) környéki sírmezőket ásatva a pálos kolostornak meghatározott palmettás bodrogmonostori kőtöredékeket a kivitelezés stílusa alapján az aracsi követ faragó mester munkájával azonosította (Raffay, 2005). Feltételezését más források is megerősítik annyi eltéréssel, hogy a kapcsolat nem egy véső müködésén alapszik, hanem pusztán stílusbeli (Tóth, 2000 
(2007)). A honfoglaláskori földvár, a mellette megjelenő település és parókia a megye leggazdagabb vidékén, a Duna és a Vajas folyó között állhatott, a baranyai Duna-rév közelében. Győrffy feltételezése szerint István király a Botond nemzetség szállásterületén szervezte meg a bodrogi várispánságot (Györffy, 1987). Bodrog vára a Dunától nem messze, Bezdán alatt, a mai Monostorszeg közelében állott" (Borovszky, 1909 (2004)), a Duna és a Mosztonga patak övezte mocsaras területen: ,„,Egy 90 éves öreg még emlékezik, hogy a falu mögött elfolyó Dunából 2 templom- és egyéb épületromot látott kiemelkedni, amit most már mindent a Duna elnyelt; az lett volna a régi Bodrog (vagy talán inkább a paulinus klastrom temploma)? Bevallják azt is, hogy mult években egy vörös feliratos követ találtak a régi telep templomában, amely bizonyára felvilágosítást adhatott volna Bodrogra vonatkozólag, hanem lelkészök és a szolgabíró a Dunába vetették, nehogy »idővel az urak között sok veszekedések okozójává lehessen«. (Iványi, 1909 (1991), I-II, 39-40).

A nehezen járható terep biztosította a vár külső védelmét, a Duna felügyeletét ${ }^{6}$, $\mathrm{s}$ ezzel a kalocsai érsekség védelmét is. Az első bodrogi ispán (Lambert) az oklevelek tanúsága szerint 1135-ben tünik föl. A megye déli vidéke ,rendkívül termékeny; folyói halakban bővelkednek, legelöin dúsan tenyészik a kövér fü, s így érthető, hogy e terület már a legrégibb időkben is alkalmas helyül kínálkozott a letelepedésre, a halászattal és marha-tenyésztésel foglalkozó nomád népeknek" (Borovszky, 1909 (2004)). Legendaszövegünk tanúsága szerint 1095. március 25-én érkezik Bodrog várába Szent László király. Itt tölti a húsvéti ünnepeket, itt fogadja a clermonti zsinat küldöttségét, s vállalja a Szentföldre indítandó kereszteshadjárat vezetését:

Annak utána méne alá Bodrog vármegyében húsvét napjára, es mikoron ott vóna, íme, Franciából, Hispániából, Angliából es Britanniából követök jevének hozjá, kérvén őtet, hogy lenne fejedelmök es előttök járó, hogy az szent Jeruzsálemnek várasát szabadojtanák meg az saracénusok kezökből es hatalmasságokból, bosszút állván Krisztus Jézusnak szent haláláért őrajtok: Azt hallván kegyes Szent László királ, nagy erembe lén rajta, es azon húsvétnak innepében elbúcsúzék az magyari uraktúl; az szegén Magyarország kedég nagy bánatban, keserüségben esék rajta, hogy az ő kegyes atyjok elhadná (...)Mikoron az határra jutott vóna, nagy erős betegségben esék. Megértvén azért Szentléleknek malasztjából, kivel teljes vala, az kegyes Szent László királ, hogy életének vége lenne, szent gyónással, töredelmességgel es Krisztus Jézus szent testének, vérének vételével megerösöjté ő halálát... (Szent László királnak legendája. Érdy-kódex, 1526, Elkezdetik immár szent királ élete, para. 10-11)

\footnotetext{
Bodrog várától nem messze, Küllőd (Kolut) határában az 1768. évi kamarai és az 1880. évi katonai térkép is megjelöli egy stratégiai szempontból azonos funkciójú, egyidejü földvár, Békavár helyét: ,,az 1887. évi forró nyár folyamán a víz kiszáradván, régi romok tüntek fel, amelyeket azonban még nem vizsgált meg senki. Ezen romok a régi, 1482-ben emlitett Kolluti várnak maradványai, mely már 1483-ban Békavárnak is neveztetett (...) Az itt volt régi kolluti várról pedig 1870-ben családi tradició alapján egy öreg béregi lakos azt mesélte, hogy ezen vár hajdanában lánccal volt összekötve a dunántúli Kiskőszeg vagy Batina hegyvárral, hogy a hajókat a Dunán megállítsák” (IVÁNYI 1906 III-V (1991): 19).
} 
Történészeink cáfolják a fentieket: „Időről időre előkerül a legenda, miszerint a Clermontban összegyűltek Szent László magyar uralkodót (ur. 1077-1095) választották meg a keresztesek fôvezérének, de ekkor a lovagkirály már négy hónapja halott volt; másfelől pedig „Krisztus katonái” nem egyetlen vezető alatt indultak meg a muszlimok ellen" (Tarján 2014, para. 3). Bodrog vármegye székhelye, Bodrog fekvésénél fogva is kedvező helyzetben van. A Kalocsától induló, Szeremlén, Bátmonostoron, Hájszentlőrincen ,Bodrogváron, Bácson, a péterváradi réven, Szerémségen át, Nagyolaszi mellett a Balkán felé vezető út sokban hozzájárul Bodrog városiasodásához (Koszta, 2000). A megyeszékhelyen városi iskola is müködött, melynek meglétéről és István nevü tanítójáról 1468-ból van adat. Pálinkás szerint „István tanító világi ember lehetett, mert a mezőváros négy papjának nevei között az övét nem említik" (Pálinkás, 1984, 27). A fentiek ellenére a XIV. század második felétől Bodrog lassan háttérbe szorul. 1360-ban említik írott források először a vártól kissé délebbre fekvő Czobor Szentmihályt (a mai Zombort).

\section{BÁCS}

Bács vármegye központja, a bácsi vár, a város és az érseki székely a Mosztonga-ér partján épült. Az István király alapította vármegye- és egyházi központ első ismert vezetője Vid ispán, aki a történeti kútfők szerint 1071-ben bácsmegyei fegyvereseivel részese Nándorfehérvár bevételének (Iványi, 1906 (1991) III-V, 10), 1074-ben pedig a mogyoródi csatában harcol a bácsi zászlóalj élén (Borovszky, 1909 (2004)). A várat 1192-ben említik először.

I. László király az I. István alapította kalocsai érsekség székhelyét a XI. század végén Bácsba helyezi át. 1090 körül székesegyházat építtet, és káptalani iskolát nyit a városban (utóbbinak a XV. század derekán már egy egyházjogi doktori végzettségű oktatója is van). László intézkedését az is magyarázhatja, hogy az akkor már virágzó Bácsban görögkeleti egyházszervezet múködik görög szerzetesek vezetésével, miután 1072-ben ide telepítették a szerémi görög püspökséget. A középkori Magyarország 15 székeskáptalani és 12 társas-káptalani iskola közül öt (Csanád, Bács, Titel, Kö, Hájszentlörinc) müködött az egykori Bácskában, Torontálban és Szerémségben. „Ennyi káptalani iskolája a középkori magyar állam nagyobb országrészeinek sem volt. Ennek egyik oka a római egyház állhatatossága, hogy a görögkeleti szlávokat és görögöket a katolikus vallásra térítse. A másik ok pedig az eretnekmozgalmak korai megjelenése ezen a vidéken" (Pálinkás, 1984, 17). Az arab Al-Idrisi „Tabula Rogeriana” c. munkájának feljegyzései szerint Bács híres város, amelyet a többi nagyvárossal együtt tartanak számon. Bácsban piacok, kereskedések, iparosok és görög tudósok találhatók. A városnak gazdaságai és múvelt földjei vannak. A búza igen olcsó, mert sok terem belöle (Elter, 1985). Müvében Al-Idrisi megbízható adatokat közöl a korabeli Magyar- és Csehország, Ausztria valamint a Balkán városhálózatáról is. A régió több tucat városát meg is nevezte, számos esetben kitért az adott város kereskedelmi jelen- 
tőségére, bár ritkán foglalkozott az egyes települések lakosságának etnikai öszszetételével. Az egyik kivétel ez alól Bács. (Nagy, 2009, 12, 83).

A XII. században a bácsi érsekség a boszniai bogumilizmus elleni küzdelem egyik főbb központja. Egy századdal később ide menekül a szerémségi huszitákat üldöző inkvizítor, Marchiai Jakab elől, és itt tagadja meg az eretnek tanokat a kamonci kápolna papja, Balázs mester.

A vár fénykora a reneszánsz idejére tehető. Mátyás király fökancellárja és országos kincstárnoka, Váradi Péter (1481-1501) azok közül való, aki rátermettségével küzdi föl magát magasabb pozícióba. Vitéz János fölfedezettje, őt követve először Esztergomba kerül, majd innen indul Bolognába, ahol egyetemi tanulmányait végezi. Itáliából hazatérve rövid idő alatt hihetetlen karriert fut be: először királyi titkár, majd pár év múlva a kancellária vezetője lett. 1480-ban kinevezik a Bács-kalocsai érsekség élére, $s$ hivatalából eredően építi ki bácsi udvarát. Váradi Mátyás király kegyence és a királyi udvar diplomatája. Ö írja a legfontosabb diplomáciai leveleket. Teszi mindezt 1484-ig, kegyvesztettségének évéig. Árva, majd Visegrád várának börtönéböl 1490-ben, a király halála után szabadul. Az elkövetkezö öt évben visszavonul, felhagy a politikával, az egyházmegye ügyeivel és a bácsi vár megerősítésével foglalkozik. Az ő nevéhez füződik a bácsi reneszánsz központ megteremtése.

„Élete a reneszánsz fó áramában alakult: tanult egyéniség, a humanista tudományok ismeröje, az irodalom barátja. 1483-ban ő gyüjti össze és íratja könyvbe Janus Pannonius epigrammáit, amikor pedig Bácsra költözik, a még középkorias erődítményt átalakítja az új, reneszánsz ízlés szellemében... Bácsott vele van könyvgyüjteménye is, amely nem olyan gazdag ugyan, mint a királyé Budán, de a reneszánsz ember ízlésének, igényének nyilvánvalóan megfelelt” (Bori, 1998, 19).

Könyvtárában a vallásos könyvek mellett a római írók kötetei is megtalálhatóak: „Philippus Beoraldus például egyenesen Váradi Péternek ajánlja a híres ókori szerelmi regénynek, Apuleius Aranyszamarának új kiadását” (Bori, 1998, 20). Könyvtárát a törökök pusztítják el. Mindössze három kötet maradt fenn az impozáns állományból, melyek közül ,,az egyik el van látva kézjegyével is. Alighanem éppen könyvtárszobájában írhatta pompás leveleit, amelyek a kor müveltésének fontos dokumentumai" (Kalapis 2003, 997).

„A török sereg 1526. szeptember 29-én vette be Bács várát és azt 1689-ig elfoglalva tartotta. 1704-ben Rákóczy csapatai a várat felgyujtották, 1705-ben Fulk császári várkapitány végképp lerontatta és ma már csak a romjai tartják fenn a hajdan oly nevezetes vár emlékét. A török megszállással Bácsnak érseki székhely jellege is megszünt és nem is támadt fel többé" (Winkler, 1926, 11). 


\section{SZERÉM}

\subsection{A szerémi borkultúra}

A Dél-Alföldre betelepülö, nomád gazdálkodást folytató magyarságot az ország nyugati részeitől eltérőn az első századokban más hatások, áramlatok érik. Fügedi Erik szerint a régió települései az ázsiai (nomád) típusú városok jegyeit viselik magukon (Fügedi, 1981), mert Magyarországnak ez a vidéke a 11-12. században elsősorban a keleti »gazdasági világ« áramába kapcsolódik (Zsoldos, 1997). A Hispániában tanult, majd Szicíliában élt arab, Idríszí csak a kijevi, bizánci kereskedelmi útvonal mentén fekvő városokat (Bács, Keve, Nagyolaszi, Titel, Csanád) jellemzi virágzó, gazdag településként. Magyarország városai közül ekkoriban ezek a legurbanizáltabbak, jól építettek, a legnagyobb gazdagsággal és a legtöbb majorsággal rendelkeznek (Elter, 1985). A déli részek városai keleties bazárvárosok, olyan települések lehettek, amelyekben a nomád sátrak magyar lakói több nációt, különböző életmódokat folytató népeket (pl. mohamedánokat) is megtürtek maguk mellett (Kristó, 2000). A fentiekből eredően a szerémségi Nagyolaszira kezdetben a nomád állattartás jellemző. A Szerémség termékeny földje „lónevelő síkság” (Elter, 1985). Másrészt Szerém a balkáni-magyar kereskedelem terepe. Az Árpádkori öt pénzverőkamra egyike Szerémben található (Simon 2007, 17).

Szerémség az egyetlen terület a középkori Magyarországon, ahol a római szölőtermesztés nyomai igazolhatóak. Probus császár Kr. u. 272-ben ültettette el az első szőlővesszőket az Alma Monson (Álmos-hegyen). „Probus szőlőt telepíttetett, hogy szülőföldjét felvirágoztassa. De a békés munkára fogott, mocsarat lecsapoló, szőlőt telepítő katonái fellázadtak, az ókori szerzők és a népi legenda szerint szőlőkarókkal agyonverték császárukat" (Csoma, 2006b, 32). A 11-14. század között több hullámban neolatin (francia, vallon, olasz) telepesek érkeznek Eger, Tokaj, Székesfehérvár és Szerém vidékére. Nagyolasziban újratelepítik a szőlőt. Szerém a zamatos, édes fehér borok, a furmint borszőlő vidékeként híresül el. A furmint történetével Gombocz Zoltán és Bárczi Géza foglalkozott.

Megállapították, hogy a közfelfogással ellentétben nem olasz betelepülök hozták Magyarországra a tatárjárás után. Gombocz kimondottan francia eredetű szónak és észak-francia szőlőnévnek tartotta »búza-szőllő«-értelemben, ami az aszalásra, töppedésre utalt. Bárczi már határozottan bizonyította, hogy a furmint nem olasz, hanem észak-franciaországi, középkori fajta volt, és a német közvetítést kizárva a XII-XIII. századi észak-francia, vallon betelepüléssel hozható kapcsolatba magyarországi megjelenése (...) Mindez a Szerémségre is igaz lehet. (Csoma 2006b, 33).

Az 1150-ben létrejött vallon Francavilla település és a fölé emelkedő Frankhegy (Fruška-Gora) évszázadokig meghatározó szerepet játszik a magyar borászatban. A szerémségi borokat messzi földre szállítják (a Felvidékre, Krakkóba). A Frank-hegyen elterülő szőlőbirtokok tulajdonosa jórészt egy idegen (extraenus) birtokos réteg. Számos délmagyarországi városnak, polgárnak van itt szőleje: 
A középkori szerémi borok a Dunán Esztergomig hajón, majd szekereken, illetve a Tiszán folytatták útjukat. A vámosok is legértékesebbeknek tartották ezeket a borokat (a baranyai, somogyi elé helyezve őket). Zsigmond király szigorú parancsban hagyta meg 1387 novemberében, hogy ne akadályozzák a Szerémségben megtelepedett raguzai kereskedőket frissen szüretelt boraik elszállításában. 1510-ben a Pesten lakó Temesvári Bodó Mihály végrendeletileg rendelkezett ötven hordó szerémi és somogyi boráról. De más budai polgárnak is volt szerémi bora, sőt szőlőbirtoka is. De a Bács megyei tizedjegyzék szerint is 1522-ben 77 szegedi patrícius polgár extraenus birtokosként Péterváradon, Kamoncon, Karomon, Szalánkeménben és Szerlökön szőlőbirtokkal rendelkezett. A szegediek voltak a szerémi borok legnagyobb kereskedői. (Csoma, 2008, 9, Volt egyszer egy borvidék, para. 5).

Mátyás király reneszánsz udvarában az egyik legkedveltebb természetes csemegebor a szerémi édes fehérbor, a szerémi aszú (Csoma, 2006a, 3-4, 396). Galeotto Marzio, Antonio Bonfini és Vitéz János egyaránt feltétlen híve a visegrádi vár vörös márványszökőkútjából csordogáló vélhetően szerémi, aranyló nedünek. A sárgás színü, aranyló aszúborhoz a szőlőben termő arany legendája kapcsolódik. Galeotto a Mátyás-kultuszt építgetve nemcsak a a szőlő aranyhajtásait véli látni, „hanem azt is kijelentette, hogy van egy arany gyürüje, amelyet a szölön termö aranyból készített” (Csoma 2006b, 34). Ekkoriban „Magyarország európai hatalom, lakossága annyi, mint Angliáé, a népesség több mint nyolcvan százaléka színmagyar" (Domonkos, 2013, 5, para. 7). Kiváltságos helyzete van a szeréminek.

Eljut a szerémi bor oda is, ahova más bort nem engednek be. Az 1403-ban kelt „Sajószentpéteriek végzése boraik kiárulása felöl" címü rendelkezésből tudjuk: idegen bort tilos volt a városba bevinni. Ellenkező esetben „A hordót mindiarost kyvonattiuk és az város közepeth az fenekéth kivágattiuk és az bort a földvel megemésztettiunk”. Kivétel a „Zerémi” bor, mert „ezek mindenütt kedvesek mi sem akarjuk megalázytani. (Domonkos, 2013, 5, para. 5).

A középkori szerémi borkultúra végét is a török veszedelem hozza meg. II. Ulászló (1490-1516), a füszerezett olasz csemegeborok kedvelöje „midőn hírét vette a Szerémség mind nagyobb méreteket öltő, folyamatos pusztulásának elkeseredetten felkiáltott: »immár most nagy baj köszöntött reánk, elesett Szerém, arra kényszeredünk, hogy tokajit igyunk...!"”" (Domonkos, 2013, 5, para. 8). A vallonok. 1521-ben Tokaj vidékére menekülnek, a török elöl Szerémbe érkező szerbek pedig egy más, nem kevésbé népszerü, közkedvelt borkultúrát honosítanak meg a Tarczal-hegyen. A balkáni nyílt erejesztésü vörösbor kultúra kadarka szőlőfajtájából készül Péterváradon és Karlovácon a rác ürmösnek nevezett (ürömmel, ezerjófüvel, kálmosgyökérrel, angelikagyökérrel, kakukkfüvel) ízesített vörös ürmösbor, a kadarka. A budai szerbek még 1831-ben is készítenek rácürmöst vörösborból (Csoma, 2008, A füszerezett borok, para. 9). A tabáni kisvendéglök népszerü itala Nagy Ignácz: Magyar titkok c. regényének szövegalkotó eleme:

És mi csúsztatja le a jó zsíros falatokat? Először az ürmösök király, az úgynevezett rácz ürmös, mely egészen megfelel politikai jellemének, nem zajoskodik, nem 
pattog, nem habzik, hanem alázatos édességgel csúszik le torkunkon, s nagyon itatja magát, midőn azonban már lenyeltük, s szájunkat megtörlöttük, akkor csodálkozva érezzük, hogy utóíze mégis keserü s kissé émelygős. Ámde a tökéletes üröm-öröm bajnokai igen ügyesen tudják ezen kellemetlen hatást megelőzni: ők ugyanis újonnan isznak, mielőtt még a keserüség és az émelygés beköszönthetne. (Nagy, 1908, Üröm-öröm, para. 24).

\subsection{Kamanc}

A XIV. század végén a Dél-Alföld az ország leggazdagabb, legsürübben lakott vidéke. A tisztán magyar népességű régió élénk kapcsolatokat tart fenn Itáliával. A bácskai földeken a török megjelenéséig tizenkét vár, huszonnyolc város és ötszázhuszonkilenc kisebb település áll, nyolc apátsággal és prépostsággal. Termékeny és sürün lakott terület.

Kamancon (Sremska Kamenica) jön létre a régió második városi iskolája. Első említése 1508-ból való, alapítása a XV. század első felére tehető (Pálinkás, 1984). A latin nyelv tanítása ezekben az iskolákban az anyanyelv alkalmazásával, latinmagyar szójegyzékek készítésével történt.

Ez idő tájt működhetett segédtanítóként (praeceptor) a kamonci iskolában Musnai János, akit Szerémi György ajánlatára Zápolyai János 1520-1540 között megtett csanádi püspöknek. Bizonyos jelek arra mutatnak, hogy ez a városi iskola már korábban fennállhatott. Ha csak magát a huszita bibliafordítást vesszük tekintetbe, abból is kiviláglik, hogy a XV. század elején a munkát végző két kamonci klerikus diáknak, Bálintnak és Tamásnak valahol meg kellett tanulnia latinul, de anyanyelvüket is jól kellett ismerniük, hogy bibliafordításukat újabb ideológiai fegyverként használhassák a feudális egyház elleni küzdelemben. A kettőt együtt pedig csak a városi iskola latin nyelvtanítása már említett módszerének, valamint a maguk végezte anyanyelvújításnak segítségével oldhatták meg sikeresen. (Pálinkás, 1984: 27-28).

Kamancon születik meg tehát legrégebbi fennmaradt bibliafordításunk (1420 1430 között), Tamás és Bálint munkája, melynek szövegét három kódex (Apor-, Bécsi- és Döbrentei-kódex) őrzi. Kutatóink egy része a husziták mủvének tartja a szöveget. Ennek írott igazolását látják a Szalkai Balázs-féle ferences krónikában, mely szerint az 1438-39. évi huszita zavargások idején

„két deák ember ugyanazon Kamenicz városából, tudniillik Tamás és Bálint, némely eszelös emberekkel és asszonyállatokkal összebeszélvén, éjnek idején megszöktek és Moldovába mentek, hol ama két pap a mondott eretnekséget tovább terjesztvén, mind a két szövetség írásait magyar nyelvre fordították. Mennyi és mekkora eretnekség vagyon pedig ebben, amint én is olvastam; ezvilági ember el sem számlálhatja (...) mivelhogy ezt a szólást is: spiritus sanctus, így fordították: zent zelleth" (Horváth, 1896, 1, 3).

Tímár Kálmán (Tímár, 1931) és Károly Sándor (Károly, 1955) vizsgálódásai során kiderült, a fordítás szövegében nem mutathatóak ki az eretnek szóhasználat 
nyomai. A „zent zelleth” nem eretnekség, pusztán nyelvi régiség. Szabó Flóris szintén kétségbe vonja Tamás és Bálint huszita voltát, az eretnek tanokat nagyobb valószínűséggel a szintén a fenti krónikában megnevezett Balázs magiszter hozhatta magával Prágából, aki az 1420-as években járt a városban, a husziták táborita ágnak a feltűnése idején, akikhez a szerémségi husziták tartoztak:

„Délen írott adatok szerint, az áramlat a Szerémségből indúlt ki. Kamenicz polgárai bizonyos Balázs nevű fiatal embert, ki nagyon tanulékony vala, iskolázni küldtek, azzal az igérettel, hogy, ha érdemes lesz rá, a kemniczi plébániát neki adják. Balázs Párgába ment, $\mathrm{s}$ »ott emberi bölcsességgel megrakodván és a hussiták eretnekségének ördögi gonoszágával rozsdásodván, némely társaival Pannoniába s hazájába, Kameniczre visszatérvén, ezek ott a hussitaságot, mint később Balázs mester magát a hitnyomozó elött mentegette, elhintegették «" (Horváth, 1896, 1, 1).

A huszita eredetnek szószólói és cáfolói is vannak. Kniezsa István úgy gondolja, a kamonci fordításban alkalmazott mellékjeles helyesírási rendszer elve (egy betü - egy hang) és hangmegkülönböztető módja (pontok és vesszők, mellékjelek alkalmazása) Husz János 1412-es rendszerét, cseh helyesírási javaslatait követi (Kniezsa, 1952). Szabó Flóris úgy véli, ,a huszita eredet kérdése a helyesírás kérdésén áll vagy bukik" (Szabó, 1989, 121), majd hozzáteszi, a bibliafordítás helyesírása megegyezik a ferences kódexek helyesírási gyakorlatával. A két írásmód nyilván több közös (ír, izlandi vagy/és héber) forrásból eredeztethető, melyek mibenléte nem állapítható meg pontosan. Újabb időkben Korompay Kniezsa elméletét tartja elfogadhatóbbnak, noha megjegyzi, ,Joggal kérdezi Szabó Flóris: hogyan válhatott népszerüvé a ferencesek körében egy huszita (azaz eretnekektől származó) helyesírás? A válasz egyelőre csak ez lehet: nem tudjuk. Az ellenérvet komolyan kell venni: olyan jelenségre mutat rá, melyet nem tudunk nyomon követni. Ha valóban a helyesíráson áll vagy bukik a Huszita Biblia huszita volta, akkor semmi okot nem látok arra, hogy a huszita eredetet megkérdőjelezzük" (Korompay, 2006, 2, 207).

Nem kételkedett a Huszita Biblia huszita voltában Marchiai Jakab sem. Az eretnek tanok 1436 körül Szerémségből átterjedtek a csanádi, váradi és erdélyi egyházmegyébe is. A hírhedt inkvizítor „Az egyszerü olasz minorita a 30-as évek elején érkezett a bosnyák provincziába (...) 1436-ban már Magyarország és Ausztria inquisitorává nevezte ki IV. Jenő pápa" (Horváth, 1896, 1, 2), s hamarosan egy , ,inkvizició alkalmával Jakab Kameniczbe, a Duna két partján fekvő városokba és falvakba érkezvén, ott sok hussita eretneket megtérített, sírjából kiásatott és elégettetett. Ez alkalommal Balázs mester, kameniczi pap is megszökött, s Bácsba menvén, hol nagyprépost vala, megjavúlt és dicséretesen élte le hátralevő napjait" (Szalkay, 1838, XXXIII).

Burány Nándor történelmi regénye a maradók és menekülők, a hitváltók és hitőrzők perspektívájából értelmezi újra kamonci kultúrkincsünket:

„Az ellentét, amely Bálint pap és köztem fönnállt, itt áthidalhatatlan szakadékká mélyült. Ö a moldáviai kivándorlásban látta az egyetlen esélyt, én az itt

Szalkay Balázs Krónikája. Régi Magyar Nyelvemlékek. Buda, 1838. XXIII. 1. 
maradásban. Ma sem változott meg a véleményem (...) Biztosra vettem, hogy aki elmegy, az elvész. Megmaradni csak egy módon lehet: itt maradni! (...) Bálint sorsa iránt érdeklődtél....ő ott is megmaradt olyannak, amilyen itt volt (...) Következetes maradt mindvégig. Ahhoz az eszméhez, amelyet már Prágában is vallott. Nem a házához, nem a városhoz ragaszkodott. Egyedül a hite iránti töretlen hüséget tartotta fontosnak" (Burány, 1977, 481-482).

\section{AKTUALITÁS ÉS IDENTITÁS - KORAI KULTÚRHAGYOMÁNYUNK KAPCSOLATAI, TOVÁBBÉLÉSI LEHETŐSÉGEI}

Magyarország déli részein érezhető legtovább, a 13. század közepéig, a keleti kapcsolatok és befolyás, a keleti kultúrkör jelenléte (Kristó, 2000). Ez a „keleties indíttatású hatásrendszer" (Kristó, 2000) szorul háttérbe, tünik el a kereszténység felvételének folyamatában, amikor a keresztény értékeket, berendezéseket közvetítő nyugat-magyarországi régió befolyása megnő. A Dél-Alföld perifériává válik, az új eszmerendszer, életmód elemei, értékei megkésve, némileg módosult (torzult) formában jutnak el ide, és „Korlátlan érvényesülésüknek nem csupán a földrajzi távolság szabott gátat, hanem az a körülmény is, hogy ide azok nem légüres térbe érkeztek, hanem egy más modell szerint funkcionáló, idegen világban kellett utat törniük, nyilván nem kis objektív és szubjektív ellenállás mellett” (Kristó, 2000).

A fenti kontextusban a kereszténység tüzzel-vassal történő terjesztése időnként vér- és kulturális veszteségekkel járó traumatikus élmény.

A déli végek lemaradása kapcsolatba hozható a keleti, bizánci kultúrkörhöz kötődő Ajtony uralmával és legyürésével, a megkésett egyházmegye-szervezéssel, monostoralapítással, a magát a 13. századig fenntartó nomád életforma szívósságával. Ilyen helyzetben könnyen táptalajra találnak az eretnek tanok (bogumilok, husziták).

A középkori magyar királyság déli végeinek szinte mindent törlő társadalmipolitikai traumái a kun betörések, a tatárjárás és a török hódoltság időszaka mindent elsöpörni látszanak. „A Halotti beszéddel a XII. század végén, majd az 1244ben Rogerius mester latin nyelvü Siralmas ének a tatárjárásról címủ szövegén át a régi magyar irodalom Mohács körüli időkben sürüsödő szövegeinek fö üzenete a zokszó, a siralom, a panasz, a veszedelem felett érzett keserv versben és prózában egyaránt. Központi müfaja tehát a siralmas krónika, illetve a »siralmas panasz«..." (Bori, 2000, 12, 1124).

A középkori kultúrkör törlődéséhez, lebontásához az újra benépesülő vidék telepesei is hozzájárulnak. A magyar királyság déli végeinek szerény építészeti maradványai újrahasznosulnak. Ennek egyik példája az elárvult aracsi pusztatemplom sorsa: „Mint azt különféle források bizonyítják, a 18. században a betelepülők építőanyagnak használták a templom tégláit, jelentősen hozzájárulva az épület további romlásához" (Utasi, 2004, 41).

A déli vidékeken alakuló korai magyar kultúrkör kapcsolat a későbbi korokkal, így jelenünkkel is, megszakad. A fent tárgyalt kulturális gócok áldozatul esnek, 
„a dicső múlt” homályába vesznek. Bács-Bodrog Vármegye kultúrateremtő és identitásképző évtizedeiben nem véletlenül a helyismereti/helytörténeti, a kultúrtörténeti tevékenység a legerőteljesebb. A múltfeltáró igyekezet, az újrakezdés erejével és hitével kell megbizonyosodni arról, nem hagyománytalan ez a vidék.

A kultúrtörténeti szakadozottság jellemzi az újrakezdések régióját. A Magyar Királyság déli végvidéke (a honfoglalástól a mohácsi vészig), Bács-Bodrog Vármegye (1802-1920), a Szerb-Horvát-Szlovén Királyság vajdasági (kisebbségi) magyar kultúrköre (1920-1945), a jugoszláviai magyar nemzetiségi kultúra (19452006) periódusa végül a szerbiai magyar (2006-napjainkig) kisebbségi kultúrkör nyomán tapasztalhatók meg a különféle politikai, társadalmi traumákat követő folyamatos újjászületések, identitás- és kultúraképzések.

A fenti kultúrkörök, kulturális örökség számbavétele, megörzése, újraértelmezése, népszerüsítése, jelen idejü, mindennapi megélése teremtheti meg azokat a kulturális kapcsolatokat, identitáshálót, amelynek nemcsak múlt, de jelen és jövő ideje is lesz.

\section{KIADÁSOK}

Burány, N. (1977). Kamanci Balázs. Történelmi regény. Újvidék: Forum Könyvkiadó

Horváth, C. (1896). Hussita emlékeink. Irodalomtudományi Közlemények, 1, 1-12. http://epa. oszk.hu/00000/00001/00034/pdf/itk_1896_1 001-012.pdf

Nagy, I. (1908). Magyar titkok. Regény. Budapest: Franklin Társulat. http://mek.oszk. $\underline{\mathrm{hu} / 07500 / 07551 / 07551 . h t m}$

Szalkay Balázs Krónikája 1838. U: Döbrentei, G. (ured.) (1838). Régi Magyar Nyelvemlékek. I. kötet. 2. rész. (str. XXI-XXIII.). Buda: Magyar Tudós Társaság.

Szent Gellért püspök nagy legendája. (1983). Csóka J. Gáspár fordítása. U: Árpád kori legendák és intelmek. (str. 74-94.). Budapest: Szépirodalmi Kiadó. http://www.ehumana.hu/ arpad/szoveg/eg08-1.htm

Szent László királnak legendája (1526). U: Érdy-kódex, http://mek.niif.hu/06100/06196/html/ kozep0027/kozep0027.html

\section{IRODALOM}

Bori, I. (1998). A jugoszláviai magyar irodalom története. Újvidék: Forum Könyvkiadó, Zavod za udžbenike i nastavna sredstva.

Bori, I. (2000). JAJ! Veszedelem, dúlás, siralom. Híd, 12, 1124-1146. Hibakiigazítás: Híd, 2001, 1, 1124-1146. http://adattar.vmmi.org/cikkek/16749/hid_2000_12_11 bori.pdf

Borovszky, S. (1909) (2004). Magyarország vármegyéi és városai. Bács-Bodrog vármegye I-II. Digitális kiadás. Budapest: Arcanum Adatbázis Kft. http://mek.oszk.hu/09500/09536/ html/

Csoma, Zs. (2006a). Történeti-ökológiai és történeti-néprajzi gondolatok a magyarországi középkori francia-vallon szőlő- és borkultúráról. Studia Caroliensia, 3-4, 389-400. http:// www.kre.hu/portal/doc/studia/Cikkek/2006.3 4.szam/p-csoma.pdf

Csoma, Zs. (2006b). A szerémségi borvidék szerepe a Délvidék történeti földrajzában. U: Kókai, S. (ured.) (2006). A Délvidék történeti földrajza. (str. 31-36). Nyíregyháza: A Nyíregyházi Föiskola Földrajzi Tanszéke. http://zeus.nyf.hu/ foldrajz/konyvek/delvidek.pdf 
Csoma, Zs. (2008). Reneszánsz bor - reneszánsz élet. Korunk, 9. http://korunk.org/?q=node/9264

Dávid, K. (1996). Marosvár-Csanád rekonstrukciója. U: Tóth, F. (ured.) (1996). In memoriam Szent Gellért. Makó: Keresztény Értelmiségi Szövetség.

http://www.sulinet.hu/oroksegtar/data/egyhaztortenet/Makoi kereszteny fuzetek/pages/023/003 david.htm

Domonkos, L. (2013). Elsüllyedt földön - Szerémi szerelem. Részlet. Kortárs online, 5. http:// www.kortarsonline.hu/2013/05/arch-szeremi-szerelem/17098

Elter, I. (1985). Magyarország Idrisi földrajzi müvében (1154). Acta Universitatis Segediensis de Attila József nominatae. Acta Historica. 82, 53-63.

Fügedi, E. (1981). Kolduló barátok, polgárok, nemesek. Tanulmányok a magyar középkorról. Budapest: Magvető

Györffy, Gy. (1987). Az Árpád-kori Magyarország történeti földrajza I. Budapest: Akadémiai Kiadó

Györkös, A. (1998). Szent Gellért és az első keresztes háború. Klió, 2. http://www.c3.hu/ klio/ klio982/klio076.htm

Iványi, I. (1906) (1991). Bács-Bodrog Vármegye földrajzi és történelmi helynévtára. III-V. Szabadka: Szabados Sándor Könyvnyomdája (Szabadka: EBI)

Iványi, I. (1909) (1991). Bács-Bodrog Vármegye földrajzi és történelmi helynévtára. I-II. Szabadka: Szabados Sándor Könyvnyomdája (Szabadka: EBI)

Jankovics, M. (2007). Boldogasszony, anyánk. A magyar Mária-kultusz. Napút, 6, 47-52. http://www.napkut.hu/naput 2007/2007 06/047.htm

Kalapis, Z. (1993). Az aracsi pusztatemplom. In: Kalapis, Z. (1993). Történelem a föld alatt. Újvidék: Forum Könyvkiadó

Kalapis, Z. (2003). Életrajzi kalauz. Ezer magyar biográfia a délszláv országokból. III. P-Zs. Újvidék: Forum Könyvkiadó.

Károly, S. (1955). Első bibliafordításunk szellet szava. Magyar Nyelvőr, 3, 303-311.

Kiszely, I. (2001). A magyar nép östörténete. Budapest: Magyar Ház Kiadó. http://mek.oszk. $\underline{\mathrm{hu} / 06400 / 06403 / \mathrm{html} /}$

Kniezsa, I. (1952). Helyesirásunk története a könyvnyomtatás koráig. Budapest: Akadémiai Kiadó

Korompay, K. (2006). Helyesírástörténet, müvelődéstörténet: két tudományág dialógusa, különös tekintettel a huszita helyesírásra. Magyar Nyelv, 2, 204-209. http://www.c3. hu/ magyarnyelv/06-2/korompay.pdf

Koszta, L. (2000) (2007). Dél-Magyarország egyházi topográfiája a középkorban. U: Kollár, T. (ured.) (2000) (2007). A középkori Dél-Alföld és Szer. Szeged: Csongrád Megyei Levéltár (Budapest: NKÖEOK Szerkesztőség) http://www.sulinet.hu/oroksegtar/data/megyek oroksege/Csongrad_megye/pages/Kozepkori_del alfold_es szer/001 del alfold torteneti helye.htm

Kristó, Gy. (2000) (2007). A Dél-Alföld történeti helye a középkori Magyarországon. U: Kollár, T. (ured.) (2000) (2007). A középkori Dél-Alföld és Szer. Szeged: Csongrád Megyei Levéltár, (Budapest: NKÖEOK Szerkesztőség) http://www.sulinet.hu/oroksegtar/data/ megyek_oroksege/Csongrad_megye/pages/Kozepkori_del_alfold_es_szer/001_del_alfold torteneti helye.htm

Margócsy, I. (2012). Variánsok lehetséges és létezö összefoglaló magyar irodalomtörténetekröl. Alföld, 3. http://www.alfoldfolyoirat.hu/node/341

Nagy, B. (2009). A középkori magyar városok a külföldi utazók leírásaiban. Korall, 38, 12, 79-90. 
Pálinkás, J. (1984). Walter magisztertől a tudományegyetemig. Újvidék: Forum Könyvkiadó Raffay, E. (2005). Az aracsi templomrom. Tanulmányok az 1200 körüli évtizedek magyarországi müvészetéről I. Újvidék: Forum Könyvkiadó. http://www.forumliber.rs/pdf/books/ Raffay\%20Endre\%20ARACS\%20I.pdf

Simon, Zs. (2007). Magyarország és az oszmán birodalom közötti kereskedelmi kapcsolatok a 16. század elején. A baricsi és kölpényi harmincadok forgalma. Doktori disszertáció. Budapest: ELTE. http://doktori.btk.elte.hu/hist/simon/disszert.pdf

Szabó, F. (1989). Huszita-e a Huszita Biblia? Bírálat és útkeresés. Irodalomtudományi Közlemények, 1-2, 118-126. file://G:/Juli/ELEKTRONIKUS\%20TANK\%C3\%96NYVEK/ Huszita\%20Biblia.pdf,

Szekfü, L. (1968). Eretnekség és tirannizmus. Irodalomtörténeti Közlemények, 5, 501-516. http://epa.oszk.hu/00000/00001/00258/pdf/00258.pdf

Szügyi, F. (2008). Az aracsi pusztatemplom mint a magyar nemzeti identitás jelképe. U: Papp, R. - Szarka, L. (ured.) (2008). Bennünk élö múltjaink. (str. 329-344). Zenta: Vajdasági Magyar Müvelődési Intézet. http://www.idkm.org/tanulmanyok

Tarján M., T. (2014). 1096. augusztus 15. Lovagsereg indul a Szentföld felszabadítására. Rubiconline. http://www.rubicon.hu/magyar/oldalak/1096 augusztus 15 lovagsereg indul a szentfold felszabaditasara/

Ternovácz, B. (2013). A bogumil eretnekség a XI. századi magyar királyság déli területén. Fons, 4, 501-523. http://www.academia.edu/6106977/A bogumil_eretnekseg_a_XI._szazadi_Magyar_Kiralysag_deli teruletein._In_Fons._2013._XX._evf._4._sz. 501-523. The Bogumil_Heresy in the Southern Part of the Hungarian_Kingdom in the 11 . Century

Timár, K. (1931). Perdöntés a legrégibb magyar bibliafordítás irodalmi perében. Győri Szemle, 107-114.

Tóth, S. (2000) (2007). Az aracsi kő rokonsága. U: Kollár, T. (ured.) (2000) (2007). A középkori Dél-Alföld és Szer. Szeged: Csongrád Megyei Levéltár (Budapest: NKÖEOK Szerkesztőség) http://www.sulinet.hu/oroksegtar/data/megyek_oroksege/Csongrad_megye/ pages/Kozepkori_del_alfold_es_szer/017_aracsi.htm

Török, J. (1991). A magyar föld szentjei. Budapest: Tulipán Kiadó

Utasi, Cs. (2004). Az aracsi pusztatemplom kultusza. Hungarológiai Közlemények, 1, 39-47.

Winkler, P. (1926). A kalocsai és bácsi érsekség. Történeti összefoglalás. Kalocsa: Árpád Részvénytársaság kiadása. http://konyvtar.asztrik.hu/sites/default/files/letoltes/winkler/ tortosszef.pdf

Zsoldos, A. (1997). Az Árpádok és alattvalóik. Magyarország története 896-1301. Debrecen: Csokonai Kiadó 
Julijana Išpanović Čapo

\title{
ZASNIVANJE KULTURE NA JUŽNIM GRANICAMA MAĐARSKE KRALJEVINE
}

\begin{abstract}
REZIME
Koncentrišući se na istoriju mađarske kulture u Vojvodini, rad pokušava (u duhu interpretacije sinteze Ištvana Margočija) da sintetizuje rane, osnovne pojave i centara osnivanja kulture (Čanad, Arača, Bodrog, Bač, Srem) kulturnog istorijata mađarske kulture u Vojvodini na južnim granicama Mađarske kraljevine (južnog dela Panonske nizije). Studija takođe proučava nastajanje traumatizovanog entiteta sazdanih od kulturni društava nastalih iz multietničkih sredina, kao i njihovu savremenost (ako se još može govoriti o tako nečemu) i moguću njihovu budućnost.

Ključne reči: zasnivanje kulture, sinteza, Čanad, Arača, Bodrog, Bač, Srem, Mađarska kraljevina, Panonska nizija, Vojvodina.
\end{abstract}

Ispánovics Csapó Julianna

\section{CULTURE FORMATION ON THE SOUTHERN PARTS OF THE HUNGARIAN KINGDOM}

\section{SUMMARY}

By concentrating on the history of the Hungarian culture in Vojvodina, the present paper tries to synthesise the establishment of the Hungarian cultural history in Vojvodina, the southern part of the Hungarian kingdom, (the Southern Great Plain) convergences of culture foundation (Csanád, Aracs, Bodrog, Bács, Szerém) in the spirit of István Margócsy's synthesis interpretation. The cultural domains formed by the multiethnic communities evolving on the southern country regions of the Hungarian Kingdom, on the boundary of East and West also analyse the timeliness of an eclectic, traumatised cultural entity (if such a thing can be mentioned), opportunities of surviving.

Keywords: culture foundation, synthesis, Csanád, Aracs, Bodrog, Bács, Szerém, Hungarian Kingdom, Southern Great Plain, Vojvodina. 